\title{
Melamine sponge-based copper-organic framework (Cu-CPP) as a multi-functional filter for air purifiers
}

\author{
Van Cam Thi Le ${ }^{*, * *,}$, Tuu Nguyen Thanh ${ }^{* * *, *}$, Eunsil Kang ${ }^{*, * * * *}$, Soyeong Yoon*, Hien Duy Mai ${ }^{*, * *}$, \\ Mahshab Sheraz ${ }^{* * *}$, Tae Uk Han ${ }^{* * * * *}$, Jinjoo An ${ }^{* * * * * *}$, and Seungdo Kim ${ }^{*, * *, * * * *, \dagger}$ \\ *Department of Environmental Sciences and Biotechnology, Hallym University, Chuncheon 24252, Korea \\ **Nano-InnoTek Corporation, 123, Digital-ro 26-gil, Guro-gu, Seoul 08390, Korea \\ ***Tra Vinh University, 126, Nguyen Thien Thanh Street, Tra Vinh City 87000, Tra Vinh Province, Vietnam \\ ****Research Center for Climate Change and Energy (RCCCE), Hallym University, Chuncheon 24252, Korea \\ $* * * * *$ Environmental Resources Research Department, National Institute of Environmental Research, \\ Hwangyeong-ro 42, Seo-gu, Incheon 22689, Korea \\ ******Process Design and Development Research Center, Korea Research Institute of Chemical Technology, \\ Daejeon 34114, Korea \\ (Received 4 August 2021 • Revised 25 October 2021 - Accepted 31 October 2021)
}

\begin{abstract}
COVID-19 has drawn great attention on the necessity for establishing pathogen-free indoor air. This paper offers an insight into the potential application of a multi-purpose filter to remove fine particulates and disinfect pathogens using melamine sponge with a copper-organic framework. In-situ growth dip coating method was applied to coat $\mathrm{Cu}$-based coordination polymer particle (Cu-CPP) on melamine sponge (MS). The integration of Cu-CPPs with high crystallinity and highly active surface area $\left(1,318.1 \mathrm{~m}^{2} / \mathrm{g}\right)$ enabled Cu-CPP/MS to have an excellent capture rate $(99.66 \%)$ and an instant disinfection rate of $99.54 \%$ for Escherichia coli. Electrostatic attraction seemed to play a crucial role in capturing negative-charged pathogens effectively by positive charges on $\mathrm{Cu}-\mathrm{CPP}$ arising from unbalanced copper ions in $\mathrm{Cu}-\mathrm{CPP}$. Disinfection of pathogens was mainly attributed to catalytically active $\mathrm{Cu}^{2+}$ sites. Organic ligand played an important role in bridging and maintaining $\mathrm{Cu}^{2+}$ ions within the framework. This study highlights the design of a new capture-and-disinfection (CDS) air filter system for pathogens using Cu-CPP/MS. It can be applied as a substitute for conventional high-efficiency particulate air (HEPA) filters.
\end{abstract}

Keywords: Melamine Sponge, Cu-based Coordination Polymer Particle, Dual Functionality, Capture and Disinfection Air Filter System, Anti-pathogens

\section{INTRODUCTION}

The COVID-19 outbreak caused by the severe acute respiratory syndrome coronavirus 2 (SARS-CoV-2) has led to a severe global heath and economic crisis [1-3]. Several recognized transmissive routes for human-to-human of COVID-19 are based on airborne factors via pathogen-containing aerosol or direct exposure to large droplets exhaled by infectious patients [4-7]. Critically, individuals staying in confined-indoor spaces are highly vulnerable to viral transmission as a result of contact with coronavirus carriers [8-10]. Thus, it is essential to develop an instant air purifying system in an indoor space.

Previous studies $[11,12]$ have reported that controlling indoor air quality with an air filtration system can reduce infection and mortality risk. Since most commercial air purifiers are composed of three sequential filters (pre-filter for removing coarse particles, activated carbon filter to remove organic contaminants, and high-efficiency particulate air (HEPA) filter) to capture fine particulates, these

\footnotetext{
${ }^{\dagger}$ To whom correspondence should be addressed.

E-mail: sdkim@hallym.ac.kr

${ }^{\ddagger}$ These authors contributed equally to this work.

Copyright by The Korean Institute of Chemical Engineers.
}

air purifiers are incapable of disinfecting pathogens $[13,14]$. It has been reported that HEPA filters may capture and accumulate some pathogenic microbes, offering a habitat for them to colonize [1517]. This issue will lead to increased maintenance and replacement cost [18-20]. In this regard, it is highly desirable to develop an efficient air control system with dual functionality, i.e., particulate removal and disinfection of pathogen-containing aerogel, to prevent the spread of respiratory infectious diseases [21,22].

In recent years, coordination polymer particles (CPPs) composed of metal nodes and organic ligands [23] have drawn attention as potential materials for anti-bacterial applications owing to their high specific surface area, adjustable pore structure, controllable release rate of metal ion, and cost-efficiency [24,25]. Among several CPPs for antimicrobial applications [26-29], Cu-based CPPs are promising candidates due to their economic viability and readiness for coating on polymer surface and their high anti-microbial ability. Integrating $\mathrm{Cu}-\mathrm{CPPs}$ constructed from $\mathrm{Cu}^{2+}$ and benzene1,3,5-tricarboxylic acid (also known as HKUST-1 or MOF-199) [30] on a variety of polymers such as silk fiber, cellulosic, nylon, and so on to produce anti-pathogen filter materials has been previously demonstrated [31-33]. Interestingly, Rubin et al. [34] reported that the stability of Cu-based CPPs on natural cotton is enhanced due to strong interactions between $\mathrm{Cu}$ cations and carboxymethylation 
groups.

Another practical issue is the contact efficiency between the aerosol and the air filter. An ideal filter should be one with anti-pathogenic agents applied on a tortuous substrate such as spongy-like foam to increase the contact efficiency of pathogens during filtration and disinfection [35,36]. Melamine sponge (MS) consisting of formaldehyde-melamine-sodium bisulfite copolymer has a welldefined pore structure, allowing polluted air to flow consistently in sponge channels, thus minimizing pressure drop and energy consumption [37,38]. Importantly, MS featuring a high density of amine functional groups is advantageous for nucleation and chemical adhesion between $\mathrm{Cu}-\mathrm{CPP}$ functioning as an antimicrobial component [39-45]. Although MS has been reported to be effective for water disinfection $[38,46,47]$, no study has reported its pathogen disinfection ability in an air phase.

In this work, we successfully fabricated a hybrid air filter composed of melamine sponge as a filter substrate and Cu-based CPPs as antimicrobial components. The melamine sponge substrate not only provides a tortuosity effect for trapping bacteria, but also favors nucleation and growth of $\mathrm{Cu}-\mathrm{CPPs}$ via amine functional groups. This research aims to offer insight into the potential application of $\mathrm{Cu}-\mathrm{CPP}$ on a melamine sponge substrate as a multi-functional highefficiency particulate air (MF-HEPA) filter. MF-HEPA may substitute conventional ones made from fibers to remove fine particulates with an excellent capacity and additional ability to disinfect pathogens in air.

\section{MATERIALS AND METHODS}

\section{Materials}

Melamine sponges with a mean pore size of $134.6 \pm 41.7 \mu \mathrm{m}$ were bought from Cleanwrap Co., Ltd (South Korea). Non-woven fibers (NWF1) with a diameter of $14.5 \pm 1.8 \mu \mathrm{m}$ were obtained from Easynetworks. Co., Ltd (South Korea). Non-woven fibers (NWF2) with a diameter of $39.4 \pm 2.5 \mu \mathrm{m}$, HEPA filters made from polypropylene with a diameter of $40.5 \pm 4.8 \mu \mathrm{m}$, and coupled polyester with a diameter of $2.9 \pm 0.6 \mu \mathrm{m}$ were provided by Dongguan Co., Ltd (South Korea).

1-1. Preparation of Pathogen Solution

In this study, Gram-negative Escherichia coli (E. coli) commonly found in indoor air was selected for examining the anti-pathogen performance of $\mathrm{Cu}-\mathrm{CPP} / \mathrm{MS}$, since it is relatively safe to handle and commonly used for testing. Petri disks, vials, and other materials were sterilized in an autoclave before experiments to avoid contamination. Stock E. coli cultures were prepared by streaking onto agar plates followed by incubation at $37^{\circ} \mathrm{C}$ until colony-forming units (CFUs) were formed. A colony was moved from the agar plate to a flask containing plate count broth and incubated at $37^{\circ} \mathrm{C}$ with shaking for 6 hours.

\section{Preparation of CuCPP/MS Hybrid Air Filter}

2-1. Reagents

Benzene-1,3,5-tricarboxylic acid $\left(\mathrm{C}_{9} \mathrm{H}_{6} \mathrm{O}_{6}, \mathrm{H}_{3} \mathrm{BTC}, 98 \%\right)$, copper(II) nitrate trihydrate $\left(\mathrm{Cu}\left(\mathrm{NO}_{3}\right)_{2} \cdot 3 \mathrm{H}_{2} \mathrm{O}, 99 \%\right)$, and ethyl alcohol $\left(\mathrm{C}_{2} \mathrm{H}_{5} \mathrm{OH}, 95 \%\right)$ were used as received. All stock solutions were freshly prepared before each reaction.

2-2. Synthesis of CuCPP/MS Hybrid Air Filter

A typical synthetic paradigm for the growth of $\mathrm{Cu}-\mathrm{CPPs}$ on $\mathrm{MS}$ is demonstrated as follows. First, $98 \mathrm{~cm}^{3}$ MS used as a substrate was soaked in ethanol, sonicated at room temperature for $30 \mathrm{~min}$, and dried under vacuum prior to the preparation of $\mathrm{Cu}-\mathrm{CPP} / \mathrm{MS}$. Then pretreated MS was immersed in $105 \mathrm{~mL}$ of aqueous solution containing $\mathrm{Cu}\left(\mathrm{NO}_{3}\right)_{2} \cdot 3 \mathrm{H}_{2} \mathrm{O}(3.81 \mathrm{~g})$ for $2 \mathrm{~h}$. To the above mixture, $105 \mathrm{~mL}$ of ethanol solution of $\mathrm{H}_{3} \mathrm{BTC}(1.84 \mathrm{~g})$ was added before ultrasonication for $4 \mathrm{~min}$. Growth of $\mathrm{Cu}-\mathrm{CPPs}$ on $\mathrm{MS}$ was carried out at $50^{\circ} \mathrm{C}$ for $12 \mathrm{~h}$. After growth completion, the resultant product (Cu-CPP/MS) was washed with ethanol several times and dried under vacuum at room temperature.

For comparison, pristine $\mathrm{Cu}-\mathrm{CPPs}$ were also prepared in the absence of MS following the synthetic procedure for $\mathrm{Cu}-\mathrm{CPP} / \mathrm{MS}$. Typically, $\mathrm{Cu}\left(\mathrm{NO}_{3}\right)_{2} \cdot 3 \mathrm{H}_{2} \mathrm{O}$ (3.81 g) was mixed with $\mathrm{H}_{3} \mathrm{BTC}$ (1.84 g) in $210 \mathrm{~mL}$ of $\mathrm{H}_{2} \mathrm{O}: \mathrm{EtOH}(1: 1)$. The reaction mixture immediately turned blue, suggesting the formation of $\mathrm{Cu}-\mathrm{CPPs}$ suspension. The mixture was further stirred and heated at $50^{\circ} \mathrm{C}$ for $12 \mathrm{~h}$ for reaction completion. Finally, blue products were purified by repeated washing with ethanol and drying under vacuum.

\section{2-3. Characterization}

All materials were imaged using a Hitachi S-4800 scanning electron microscope (SEM) and a JEOL JEM-2010 Luminography (Fuji FDL-5000) Ultramicrotome (CRX) transmission electron microscope. Ultraviolet-visible spectra were recorded using a UV-1800 (Shimadzu, UV-vis spectrophotometer). Energy-dispersive X-ray analysis was performed using a JEOL JEM-2100F microscope. Powder X-ray diffraction (PXRD) was performed using a Rigaku Ultima IV diffractometer with focused-beam $\mathrm{Cu} \mathrm{K}_{\alpha}$ radiation $\left(\mathrm{K}_{\alpha}=1.541 \AA\right.$ ) at a continuous scan rate of $0.09^{\circ} \mathrm{min}^{-1}$ in the range of $5-80^{\circ}$. Simulated PXRD pattern of $\mathrm{Cu}-\mathrm{CPP}$ was calculated from single-crystal $\mathrm{X}$-ray diffraction data using the Mercury 3.3 program. $\mathrm{N}_{2}$ adsorption isotherms were obtained using a BELSORP-mini II (BEL Japan, Inc.) instrument. Gases used throughout the adsorption experiments were highly pure (99.999\%). Prior to adsorption experiments, all samples were activated by thorough rinsing with ethanol, followed by drying under vacuum for $12 \mathrm{~h}$ prior to gas sorption measurements.

\section{Capture Experiments}

\section{3-1. Experimental Device}

The experiment design followed the report of Ramya et al. [35, 48-50] with some modifications. Fig. 1 depicts a schematic diagram of the experimental setup, which is composed of a TSI particle generator 8026 (1), a flow meter (2), a plug flow reactor containing the sponge sample (3), an S-Pak membrane filter (4), and a bleach solution (5). The generated microbial aerosol transfers through the rectangular prism reactor holding the sponge air filter sample. The sterile membrane filter with a pore size of $0.22 \mu \mathrm{m}$ traps the outlet stream including $E$. coli bacteria with a cylinder of 1.0-2.0 micrometers in length and a radius of about 0.5 micrometers. For safety purposes, the outlet stream from the module then passes into the bleach solution. The whole device is located in a safety cabinet to ensure sterility of experiments.

\section{3-2. Pathogen Capture Test}

Capture experiment procedures for MS and $\mathrm{Cu}-\mathrm{CPP} / \mathrm{MS}$ composite foams are described in Fig. S1. In the first step, E. coli-comprising aerosols had particle diameters ranging from $1 \mu \mathrm{m}$ to $5 \mu \mathrm{m}$ size, similar to diameters of droplets produced by a human sneez- 

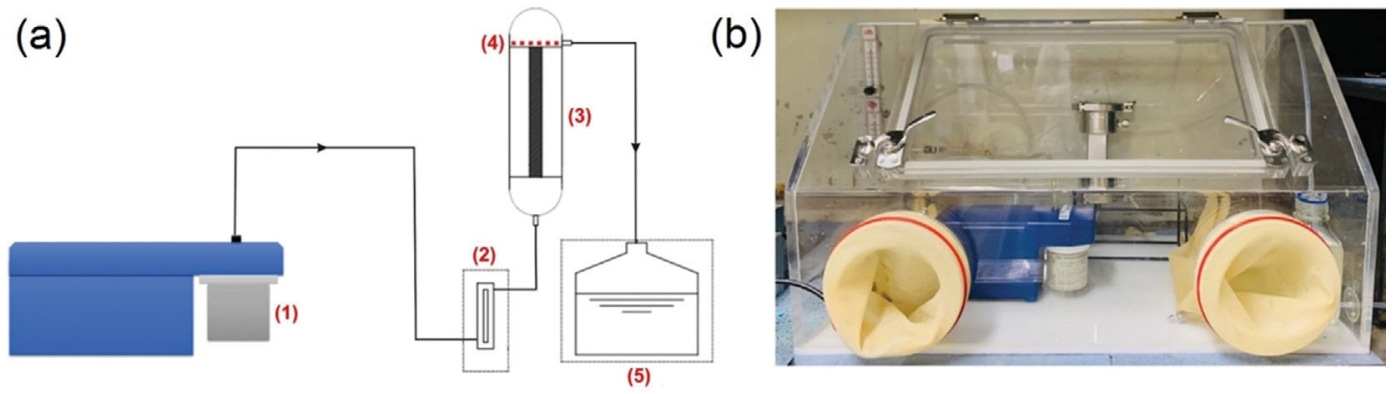

Fig. 1. Schematic figure (a) and Digital camera (b) image of an antibacterial rig consisting of a TSI particle generator 8026 (1), a flow meter (2), a plug flow reactor containing the sponge sample (3), an S-Pak membrane filter (4), and bleach solution (5).

ing or coughing. E. coli suspension at $2 \times 10^{6} \mathrm{CFU} \mathrm{mL} \mathrm{m}^{-1}$ was sprayed into the reaction section at a flow rate of $3 \mathrm{~L} \mathrm{~min}^{-1}$ for $15 \mathrm{~min}$. Afterwards, the S-Pak membrane filter, which was deposited behind the sponge filter sample, was taken out and incubated at $37^{\circ} \mathrm{C}$ for $24 \mathrm{~h}$. Finally, the number of survival colonies was counted to evaluate the air pathogen capture performance of the sponge air filter. Blank tests were carried out to determine the number of bacterial colonies flowing through the reactor in the absence of a sponge filter sample. For comparison, conventional fiber filters composed of non-woven fibers (NWF1, NWF2, and HEPA filters) were also examined in the same experimental conditions (Fig. S1 and Fig. S2). All tests were repeated three times. Pathogen capture efficiency in air for sponge and fiber filters was calculated using Eq. (1):

$$
\text { Efficiency }=\frac{\left(\mathrm{C}_{0}-\mathrm{C}\right)}{\mathrm{C}_{0}}
$$

where $\mathrm{C}_{0}$ is the initial bacterial count estimated based on blank test and $\mathrm{C}$ is the bacterial count at the sponge outlet.

\section{Disinfection Experiments}

\section{4-1. Disinfection Test in Air Media}

The disinfection test was performed with six steps (Fig. S1). After deposition of the pathogen aerosol onto the $\mathrm{Cu}-\mathrm{CPP} / \mathrm{MS}$ sponge air filter ( $1 \mathrm{~cm}$ in thickness) for $15 \mathrm{~min}$, the removed sponge filter was kept in an incubator at $37^{\circ} \mathrm{C}$ for $45 \mathrm{~min}$. Subsequently, the foam filter was rinsed in a vial containing $10 \mathrm{~mL}$ PBS solution. The resultant eluant was dispersed into sterilized tubes containing $10 \mathrm{~mL}$ saline solution with a ten-fold serial dilution method. In the next step, the bacterial water $(100 \mu \mathrm{L})$ from the vial was plated onto an agar plate and incubated at $37^{\circ} \mathrm{C}$ for $24 \mathrm{~h}$. Finally, the number of survival colonies was counted to evaluate disinfection activity against air pathogens in sponge air filters. Pristine $\mathrm{MS}$ and $\mathrm{Cu}-\mathrm{CPP} / \mathrm{MS}$ hybrid sponge air filters freshly washed with the eluant were also cultured on plate count agar at $37^{\circ} \mathrm{C}$ for residuary analysis of attached viable cells. The pristine MS foam filter instead of $\mathrm{Cu}-\mathrm{CPP} /$ MS was also tested in the same experimental conditions for comparison.

\section{4-2. Disinfection Test in Liquid Media}

Typically, a sponge filter with a size of $2.5 \times 2.5 \times 1.0 \mathrm{~cm}^{3}$ was immersed in a bottle containing a mixture of $20 \mathrm{~mL}$ PBS and $200 \mu \mathrm{L}$ pathogen solution $\left(1.4 \times 10^{7} \mathrm{CFU} \mathrm{mL} \mathrm{m}^{-1}\right)$. The mixture was incubated at $37^{\circ} \mathrm{C}$ with shaking at $230 \mathrm{rpm}$. As the reaction proceeded, the sample was pipetted out at scheduled intervals and dispersed in sterilized tubes with a $10 \mathrm{~mL}$ saline solution by a ten-fold serial dilution method. These samples $(100 \mu \mathrm{L})$ were then added onto plate count agar as a culture medium and incubated at $37^{\circ} \mathrm{C}$ for $24 \mathrm{~h}$. Subsequently, the count of viable cells was determined to evaluate the disinfection performance. Each experiment was repeated three times.

To further clarify the antibacterial role of $\mathrm{Cu}-\mathrm{CPPs}$ in the hybrid sponge filter, $0.02 \mathrm{~g} \mathrm{Cu}-\mathrm{CPP}$ powder was added to a mixture of 20 $\mathrm{mL}$ PBS and $0.2 \mathrm{~mL}$ pathogen solution $\left(1.4 \times 10^{7} \mathrm{CFU} \mathrm{mL} \mathrm{m}^{-1}\right)$. The pathogen and the disinfectant were mixed and incubated at $37^{\circ} \mathrm{C}$ with shaking at $230 \mathrm{rpm}$ for $45 \mathrm{~min}$. As the reaction proceeded, the mixture was pipetted out at a scheduled interval and residual pathogen concentration was determined by the standard plate count method based on the number of survival colonies. For comparison, $\mathrm{Cu}\left(\mathrm{NO}_{3}\right)_{2} \cdot 3 \mathrm{H}_{2} \mathrm{O}(0.02 \mathrm{~g})$ and $\mathrm{H}_{3} \mathrm{BTC}$ ligand $(0.02 \mathrm{~g})$ were also examined under the same experimental conditions. Every test was repeated three times. The disinfection efficiency of each material was calculated according to Eq. (2):

$$
\text { Efficiency }=\frac{\left(\mathrm{C}_{0}-\mathrm{C}\right)}{\mathrm{C}_{0}}
$$

where $\mathrm{C}_{0}(\mathrm{CFU} / \mathrm{mL})$ is the concentration of $E$. coli without disinfectant and $\mathrm{C}$ is the concentration of microorganisms at each sampling time $(0,15,30$, and 45 minutes).

\section{RESULTS AND DISCUSSION}

\section{Synthesis of Cu-CPP/MS Hybrid Air Filter}

Scheme 1 illustrates the procedure to deposit $\mathrm{Cu}-\mathrm{CPP}$ on a threedimensional MS to generate porous $\mathrm{Cu}-\mathrm{CPP} / \mathrm{MS}$. Color change from white to blue was observed for MS, indicating successful integration of $\mathrm{Cu}-\mathrm{CPP}$ into MS indirectly. Heterogeneous $\mathrm{Cu}-\mathrm{CPP} /$ MS composites could be easily scaled up to answer the demand and reveal consistent patterns on dimensions or geometry of the sponge with scale-up operations.

Several substrates other than MS have been applied for the growth of $\mathrm{Cu}$-CPP. Some substrates (e.g., cellulose fiber) show relatively low adhesion toward the Cu-CPP [51]. However, toxic solvents (e.g. DMF) were used for synthetic procedures [33,52,53]. In this study, non-toxic solvents such as ethanol and deionized water were applied for the synthesis.

Scanning electron microscopy (SEM) images visually showed 


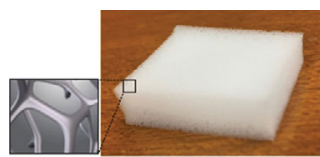

MS
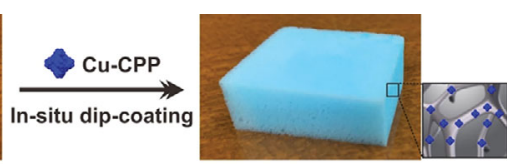

Cu-CPP/MS

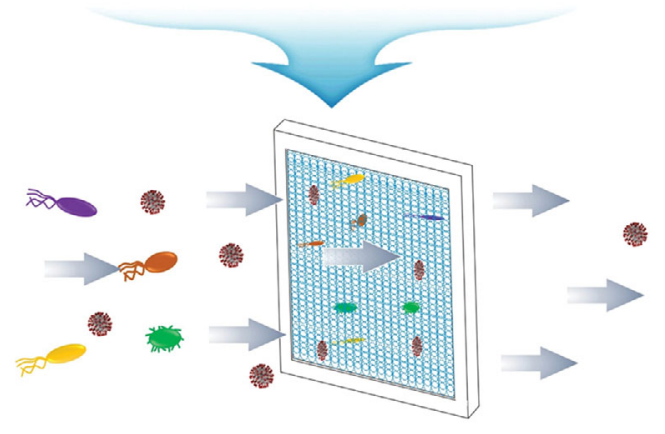

Air Capture and Disinfection System

Scheme 1. Schematic illustration of Cu-CPP/MS hybrid air filter and its application for removing pathogens from air.

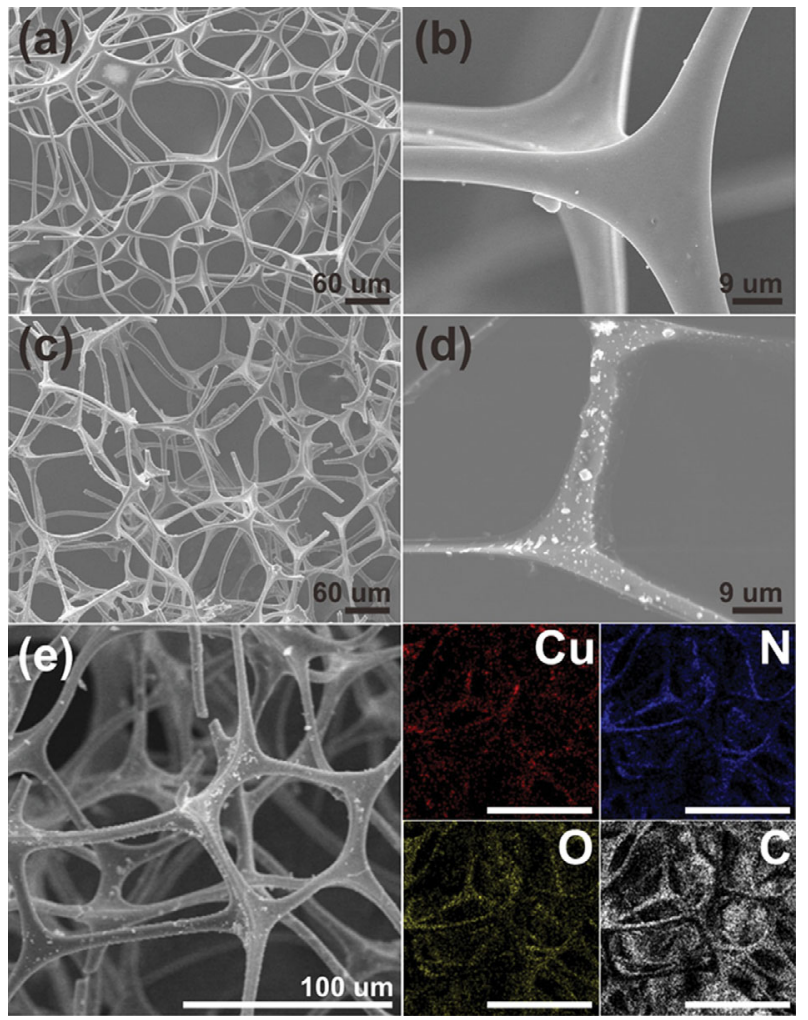

Fig. 2. (a), (b) SEM images of pristine melamine sponge, (c), (d) SEM images of Cu-CPP/MS and (e) their corresponding elemental mapping results by EDX analysis for elements of copper (in red), nitrogen (in blue), oxygen (in yellow), and carbon (in gray).

changes in the surface topography of the pristine MS before (Fig. 2(a) and 2(b)) and after Cu-CPP deposition (Fig. 2(c) and 2(d)). Fig. 2(a) and 2(b) display an open pore structure and a smooth surface of MS, whereas Fig. 2(c) and 2(d) clearly show the formation of crystals (average size of $1.77 \pm 0.43 \mu \mathrm{m}$ ) on the surface of MS without affecting its primary spongy structure. These crystals were expected to be $\mathrm{Cu}-\mathrm{CPP}$, reflecting successful deposition of $\mathrm{Cu}-$ $\mathrm{CPP}$ on the MS surface. The high degree of porosity of MS allows a facile impregnation of $\mathrm{Cu}^{2+}$ as well as $\mathrm{H}_{3}$ BTC ligand for the nucleation and growth of Cu-CPPs on the surface of MS [38].

Energy-dispersive X-ray (EDX) confirmed the uniform distribution of $\mathrm{Cu}, \mathrm{C}, \mathrm{O}$, and $\mathrm{N}$. Among them, $\mathrm{Cu}, \mathrm{C}$, and $\mathrm{O}$ were major components of $\mathrm{Cu}-\mathrm{CPP}$. $\mathrm{N}$ originated from MS, implying that $\mathrm{Cu}-$ CPP was successfully deposited on the MS surface (Fig. 2(e)). Copper content was $3.23 \%$ in $\mathrm{Cu}-\mathrm{CPP} / \mathrm{MS}$, higher than $2.28 \%$, the expected mass percent of copper in Cu-CPP/MS. It was expected that $\mathrm{N}$-pyridine and amine groups of MS would be strongly coordinated with $\mathrm{Cu}^{2+}$ in $\mathrm{Cu}-\mathrm{CPP}$ (Fig. S3), allowing facile deposition of $\mathrm{Cu}-\mathrm{CPP}$ on MS surface [39-45].

For crystallite and elemental compositions of $\mathrm{Cu}-\mathrm{CPP} / \mathrm{MS}, \mathrm{X}$-ray diffraction (XRD) and X-ray photoelectron spectroscopy (XPS) analyses were performed, respectively. The spongy structure of MS made it difficult to characterize the aforementioned properties of $\mathrm{Cu}-\mathrm{CPPs}$ on $\mathrm{MS}$ via X-ray diffraction (XRD) and X-ray photoelectron spectroscopy (XPS). Instead, we characterized Cu-CPP for crystallite and elemental compositions. Fig. S4 shows octahedral crystals of $\mathrm{Cu}-\mathrm{CPP}$ with an average size of $1.67 \pm 0.17 \mu \mathrm{m}$. Its PXRD data were in agreement with simulated ones from the database (Fig. 3(a).

$\mathrm{Cu}-\mathrm{CPP}$ also showed a characteristic type-I isotherm curve [54, 55], exhibiting a steep increase in $\mathrm{N}_{2}$ uptake at relatively low pressures (Fig. 3(b)). Hence, Cu-CPP might be a microporous material with a high surface area. Its BET surface area $\left(\mathrm{S}_{B E T}\right)$, pore volume $\left(\mathrm{V}_{B J H}\right)$, and average pore diameter $\left(\mathrm{D}_{B J H}\right)$ were estimated to be $1,318.1 \mathrm{~m}^{2} / \mathrm{g}, 0.53 \mathrm{~cm}^{2} / \mathrm{g}$, and $16.14 \AA$, respectively, higher than those of conventional activated carbon [56].

Chemical oxidation states of $\mathrm{Cu}-\mathrm{CPP}$ were revealed using XPS (Figs. 3(c)-3(d)). As illustrated in Fig. 3(c), full survey scan of the sample revealed the presence of $\mathrm{Cu} 2 \mathrm{p}, \mathrm{O} 1 \mathrm{~s}, \mathrm{~N}$ 1s. and $\mathrm{C} 1 \mathrm{~s}$. To gain more insight into the chemical state of copper on MS, highresolution XPS spectra of selected peaks were acquired. Fig. 3(d) illustrates $\mathrm{Cu}^{2+}$ peaks centered at $932.8 \mathrm{eV}$ and $952.8 \mathrm{eV}$ corresponding to $\mathrm{Cu} 2 \mathrm{p} 3 / 2$ and $\mathrm{Cu} 2 \mathrm{p} 1 / 2$, respectively [57].

To better understand the chemical composition of the MS and $\mathrm{Cu}-\mathrm{CPP} / \mathrm{MS}$, FTIR spectroscopy was carried out as shown in Fig. $3(\mathrm{e})$. For MS, the bands at $1,541 \mathrm{~cm}^{-1}$ and $1,327 \mathrm{~cm}^{-1}$ are, respectively, attributed to $\mathrm{C}=\mathrm{N}$ and $\mathrm{C}-\mathrm{N}$ vibrations on the triazine ring. The sharp absorption peak at $809 \mathrm{~cm}^{-1}$ is attributed to a bending mode of the triazine ring [58]. In addition, the absorption regions at 976 and 3,353 $\mathrm{cm}^{-1}$ belong to the twisted vibration peak of $\mathrm{N}-\mathrm{H}$ and stretching vibration peaks of N-H [59]. After the deposition of $\mathrm{Cu}-\mathrm{CPP}$ on $\mathrm{MS}$, new stretching vibration modes for $\mathrm{C}=\mathrm{O}$ (at 1,372 and $1,643 \mathrm{~cm}^{-1}$ ) and bending vibration modes for $=\mathrm{C}-\mathrm{H}$ (at 761 and $730 \mathrm{~cm}^{-1}$ ) are observed. The characteristic peaks in the $1,350-1,750 \mathrm{~cm}^{-1}$ region are due to the COO- $\mathrm{Cu}_{2}$ stretching, indicating a symmetric coordination mode [60]. Peaks in the 650-1,150 $\mathrm{cm}^{-1}$ region belong to the stretching modes of trimesic ligand [61]. These prominent peaks are consistent with the pattern of the $\mathrm{Cu}-$ CPP [62].

\section{Capture Performance}

The spongy structure and a high degree of crystallinity with an enormous surface area of $\mathrm{Cu}-\mathrm{CPP} / \mathrm{MS}$ signified its potential for 

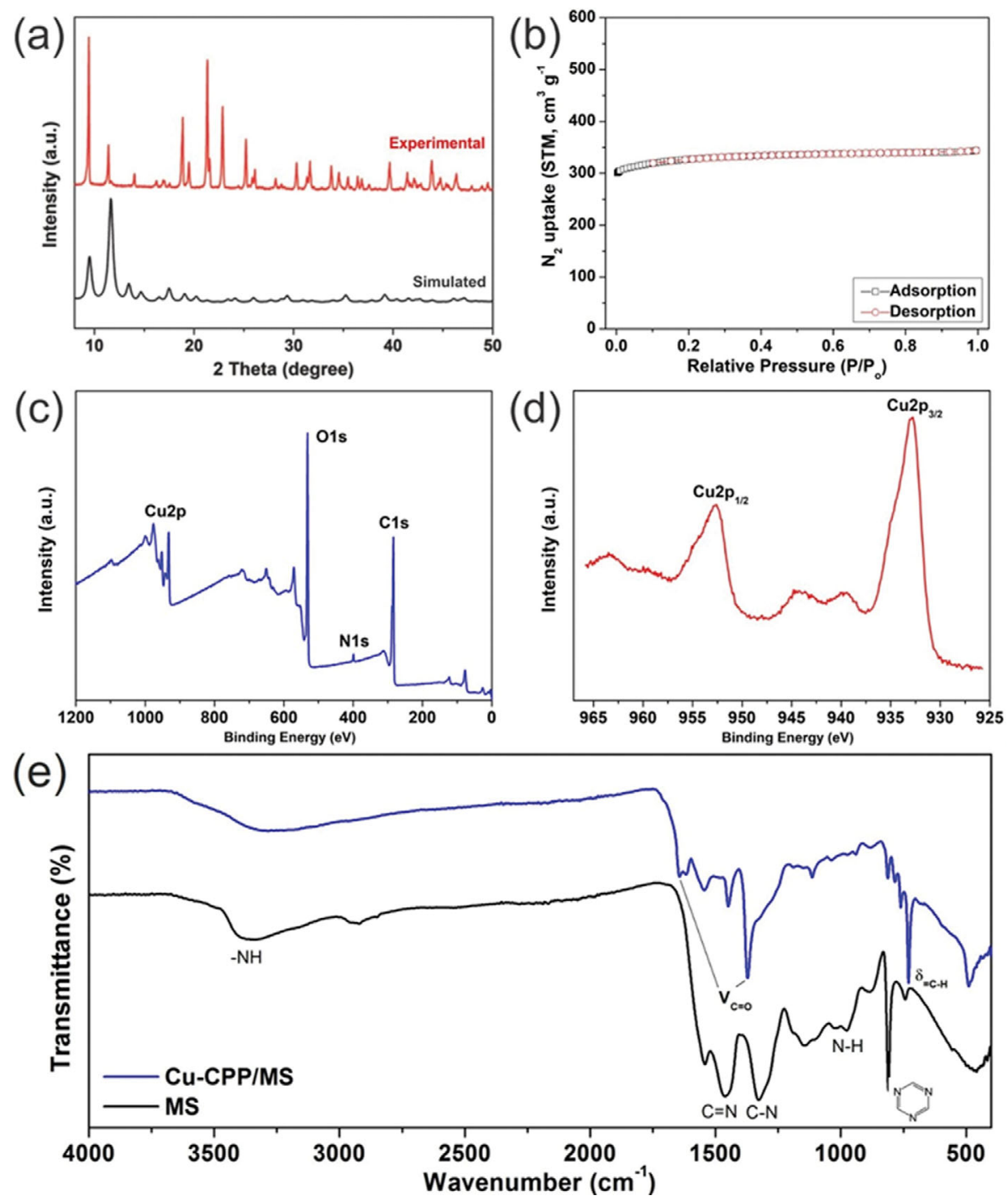

Fig. 3. (a) XRD patterns, (b) $\mathrm{N}_{2}$ adsorption-desorption isotherms, (c), (d) XPS of Cu-CPP particles and (e) FT-IR spectra of the MS and CuCPP/MS samples.

capturing pathogens. The experimental setup for examining the capture performance is schematically shown in Fig. 1. Captured performances of $\mathrm{Cu}-\mathrm{CPP} / \mathrm{MS}$ for $E$. coli are summarized in Fig. 4 and Table 1. As presented in Fig. 4(a), the blank test shows a high density of bacterial colonies, whereas few colonies are observed on MS (Fig. 4(b)) and Cu-CPP/MS filters (Fig. 4(c)). As illustrated in

Table 1. Capture efficiency comparison of Pristine MS, Cu-CPP/MS sponge filters, and conventional fiber filters composed of non-woven fibers NWF1, NWF2, and high-efficiency particulate air filter (HEPA)

\begin{tabular}{lc}
\hline \hline Filter samples & Pathogen capture efficiency (\%) \\
\hline NWF1 & 61.22 \\
NWF2 & 78.23 \\
HEPA & 99.32 \\
Melamine sponges (MS) & 95.91 \\
Cu-CPP/MS & 99.66 \\
\hline
\end{tabular}

Table 1, bacteria capture efficiency up to $95.91 \%$ is seen when MS is used as a filter, higher than that of conventional fiber filters including NWF1 (61.22\%) and NWF2 (78.23\%). Notably, Cu-CPP/ MS exhibits the highest capture efficiency, reaching $99.66 \%$, which is even higher than HEPA filter (99.32\%). These results demonstrate that $\mathrm{Cu}-\mathrm{CPPs} / \mathrm{MS}$ hybrid sponge air filter has a high bacteria capture efficiency to remove fine particulates with an equal and better capacity than conventional fiber filters.

The enhanced filtration activity of Cu-CPP/MS can be attributed to the following two reasons: 1) Cu-CPPs on MS have positive charges provided by unbalanced metal ions $[63,64]$, thereby enhancing the capacity due to electrostatic attraction between negatively charged bacterial cells and positively charged Cu-CPPs [49, 65], and 2) pathogens are simultaneously accumulated on $\mathrm{Cu}-\mathrm{CPP} /$ $\mathrm{MS}$ and inactivated as a result of contacting with $\mathrm{Cu}-\mathrm{CPP}$ [35].

\section{Disinfection Performance}

The disinfection activity of $\mathrm{Cu}-\mathrm{CPP} / \mathrm{MS}$ filter was assessed based on the difference in the number of pathogen colonies on pristine 

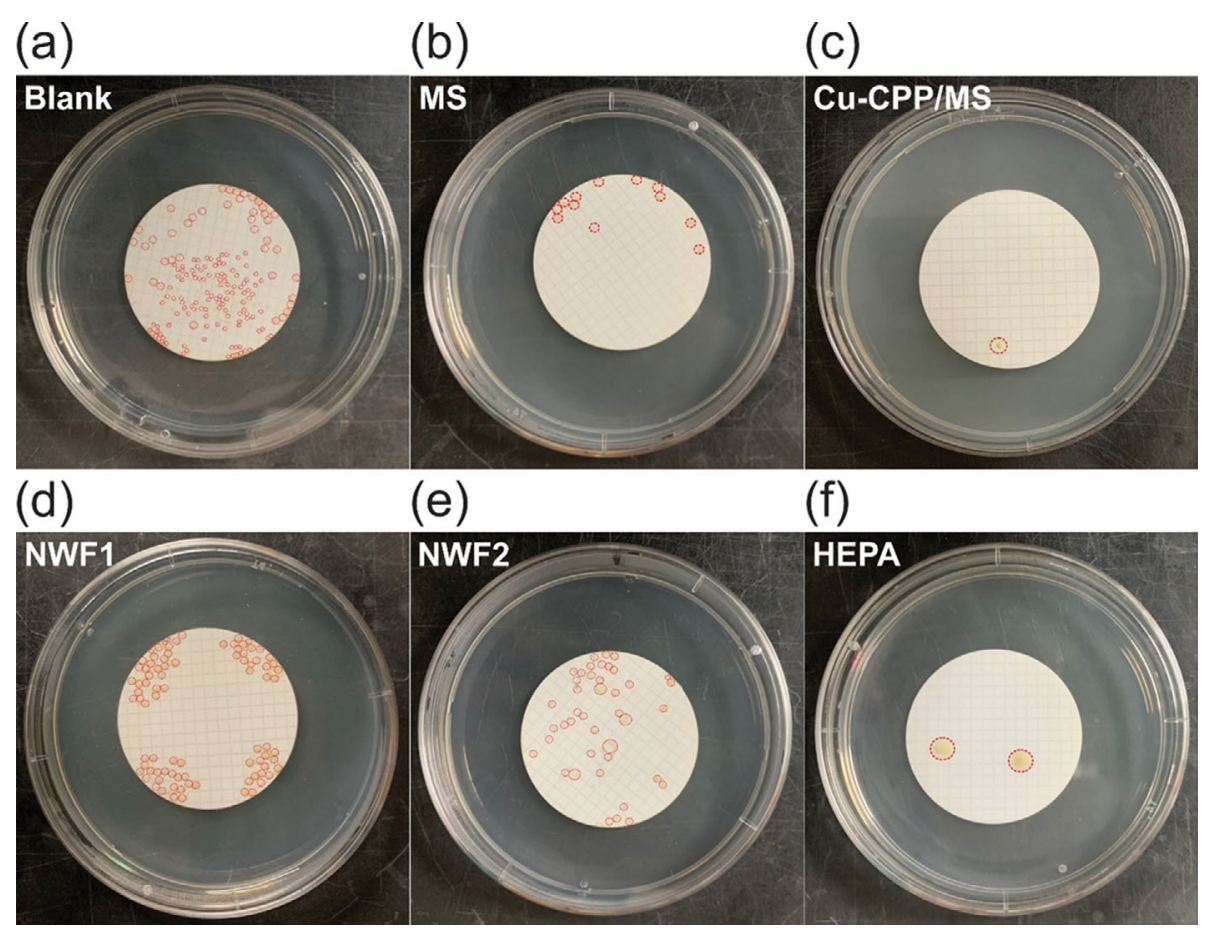

Fig. 4. Bacterial colonies residuals on membrane in pathogen capture test of (a) Blank test, (b) Pristine MS, (c) Cu-CPP/MS sponge filters, and conventional fiber filters composed of (d) Non-woven fibers (NWF1), (e) Non-woven fibers (NWF2), and (f) High-efficiency particulate air filter (HEPA).
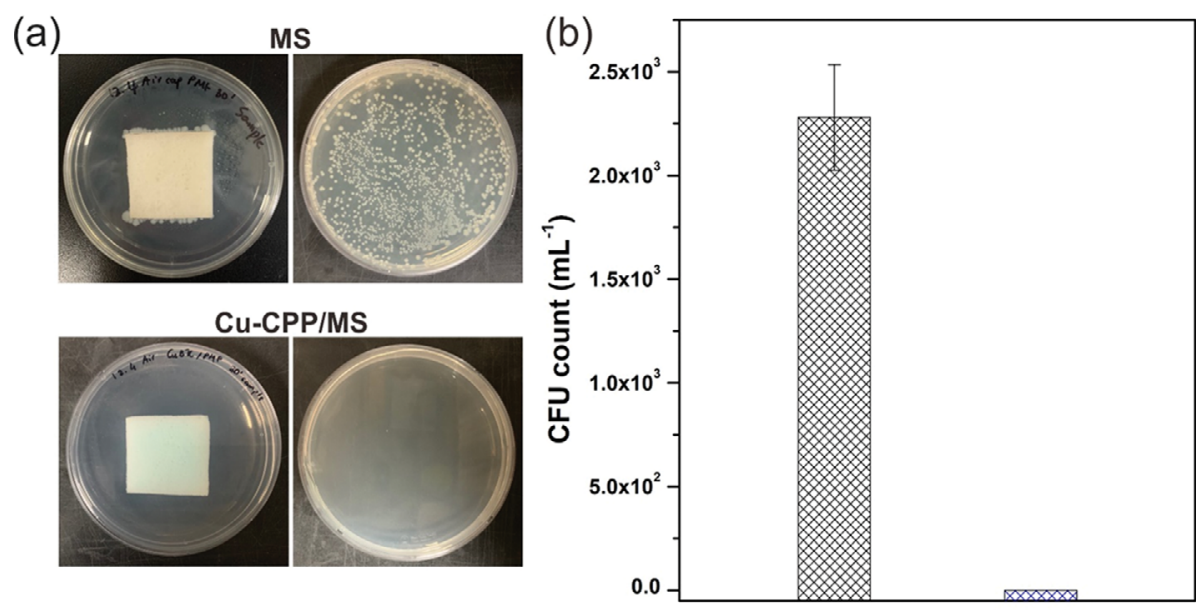

MS Cu-CPP/MS

Fig. 5. Disinfection performance comparison between Cu-CPP/MS hybrid and pristine MS air filters in air phase. (a) Digital images of bacterial colonies residuals and (b) E. coli levels residuals on MS and Cu-CPP/MS after 45 min of air incubation.

MS. Surprisingly, the number of viable bacterial cells dropped rapidly to an undetectable level of living pathogen on Cu-CPP fibers (Fig. 5). The disinfection efficiency of $\mathrm{Cu}-\mathrm{CPP} / \mathrm{MS}$ filter reached $100 \%$ within $45 \mathrm{~min}$.

We also investigated disinfection activity of pristine MS and $\mathrm{Cu}-\mathrm{CPP} / \mathrm{MS}$ in liquid phase. As illustrated in Fig. 6, MS showed a negligible efficiency for $45 \mathrm{~min}$. On the contrary, after deposition of $\mathrm{Cu}-\mathrm{CPP}$ as an anti-bacterial agent, $\mathrm{Cu}-\mathrm{CPP} / \mathrm{MS}$ showed significantly higher performance, with a disinfection efficiency of $99.5 \%$ instantly, reaching $100 \%$ after $45 \mathrm{~min}$.
To further clarify the antibacterial role of $\mathrm{Cu}-\mathrm{CPP}$ in the composite, we investigated antibacterial performance of pristine $\mathrm{Cu}$ $\mathrm{CPP}, \mathrm{Cu}\left(\mathrm{NO}_{3}\right)_{2}$, and $\mathrm{H}_{3} \mathrm{BTC}$ ligand. As seen in Fig. S5, Cu-CPPs and $\mathrm{Cu}\left(\mathrm{NO}_{3}\right)_{2}$ rapidly reached very high antibacterial efficiency of $97.36 \%$ and $98.07 \%$, respectively, much higher than that of $\mathrm{H}_{3} \mathrm{BTC}$ ligand (56.43\%). After $45 \mathrm{~min}$, both $\mathrm{Cu}-\mathrm{CPPs}$ and $\mathrm{Cu}\left(\mathrm{NO}_{3}\right)_{2}$ had an antibacterial efficiency of $100 \%$ while $\mathrm{H}_{3}$ BTC showed an antibacterial efficiency of only $62.14 \%$. These results indicate that antibacterial active species in $\mathrm{Cu}-\mathrm{CPPs}$ are based on $\mathrm{Cu}^{2+}$ metal sites [66]. However, in the structure of $\mathrm{Cu}-\mathrm{CPPs}$, the $\mathrm{H}_{3} \mathrm{BTC}$ ligand plays 
(a)

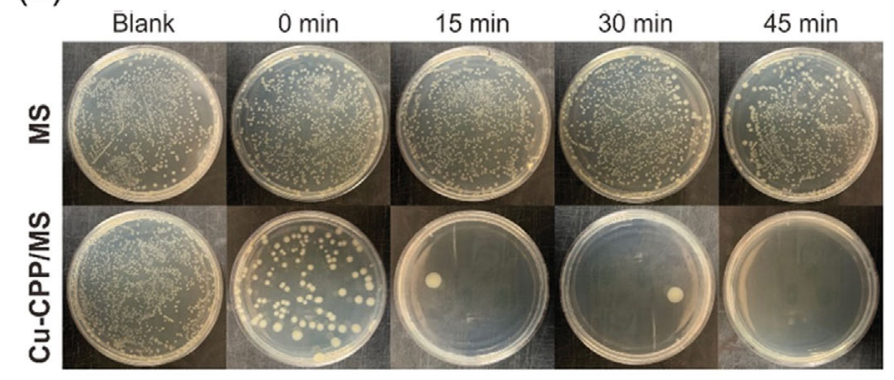

(b)

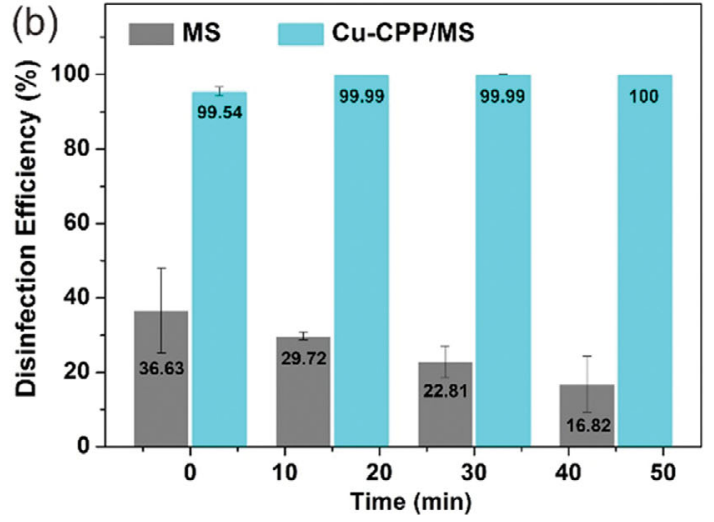

Fig. 6. Disinfection performance comparison between Cu-CPP/MS hybrid and pristine MS air filters in liquid phase. (a) Digital images of inoculated E. coli colonies on agar culture plates and (b) Disinfection efficiency of MS and Cu-CPP/MS after 0, 15, 30, and 45 min of reaction time.
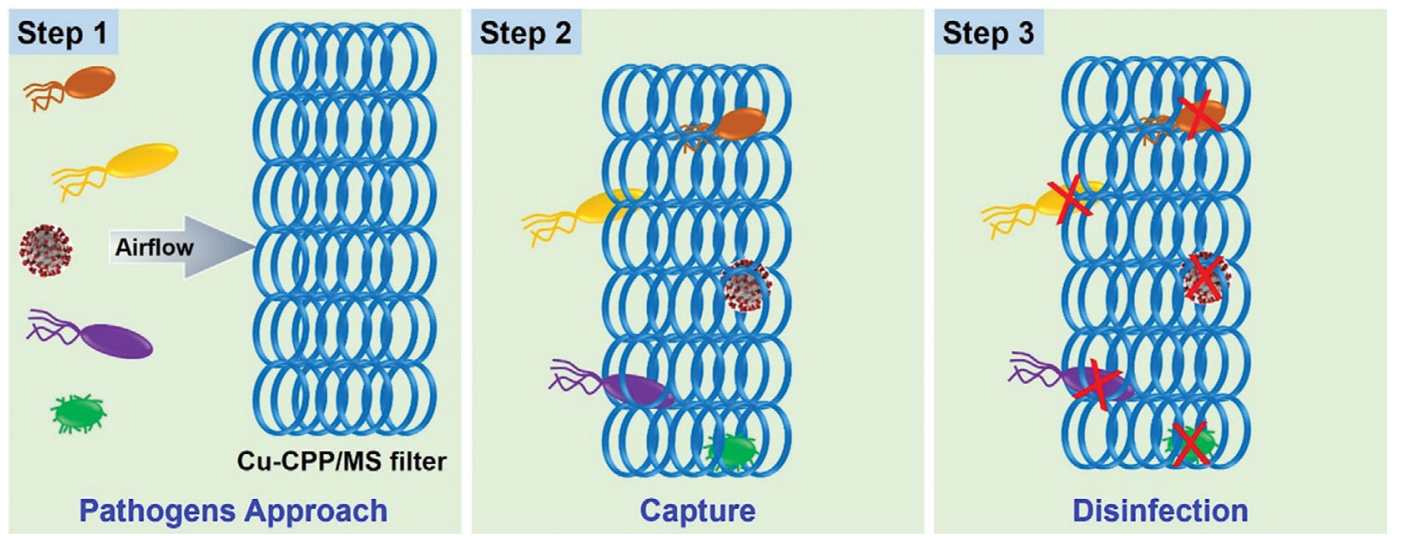

Fig. 7. Air treatment mechanism of capture and disinfection systems based on a copper metal-organic framework (Cu-CPP)-coupled melamine sponge (MS) hybrid.

an important role in bridging and maintaining $\mathrm{Cu}^{2+}$ ions within the framework. This can prevent undesirable release of $\mathrm{Cu}^{2+}$ ions into solution during the antibacterial test in aqueous solution, which is impossible in the case of $\mathrm{Cu}\left(\mathrm{NO}_{3}\right)_{2}$. Thus, the incorporation of $\mathrm{Cu}$-CPPs into MS can overcome severe drawbacks of copper (II) solution as a homogeneous antibacterial agent [67].

The superior bactericidal activity of $\mathrm{Cu}-\mathrm{CPP} / \mathrm{MS}$ filter for air samples was attributed to the incorporation of Cu-CPPs as antibacterial agents onto the MS structure. These data suggest that the uniform incorporation of $\mathrm{Cu}$-CPPs coupled with their high crystallinity and highly active surface area accounted for the antibacterial superiority of the composite. As shown in Fig. S6, the antipathogen ability of $\mathrm{Cu}$-CPPs is principally attributed to catalytically active $\mathrm{Cu}^{2+}$ sites within the framework [52,68]. Copper ion has dual disinfection mechanisms consisting of contact killing on pathogen surface or leaching and disintegrating of bacteria's internal structure upon contact. $\mathrm{Cu}^{2+}$ is readily released to gradually degrade bacterial membranes upon interaction with cells. Afterwards, it will affect permeability of the cell membrane, leading to a leakage of intracellular substances [69]. Deposited Cu-CPP particles in the composite can perform as a $\mathrm{Cu}$ ion reservoir [66].

In addition, the copper-organic framework with a large specific surface area can substantially enhance the density of exposed metal ions on the surface of MOFs. Consequently, utilization efficiency of metal active sites and contact time with bacteria can be much improved, leading to an excellent antibacterial achievement.

\section{Capture-and-disinfection Air Filter System}

As shown in Fig. 7, a capture-and-disinfection air filter system of $\mathrm{Cu}-\mathrm{CPP} / \mathrm{MS}$ was prepared with three stepwise procedures. First, aerosol containing pathogen approached the filter system as air flowed to the air purifier. Afterwards, these aerosolized pathogens were captured within the MS, thereby increasing the contact time between the pathogen and disinfectants. Finally, attached pathogens from MS were terminated due to the disinfection activity of copper metal-organic framework (Cu-CPP). Basically, the capture stage is helpful as it supports the important disinfection stage. Therefore, using such a capture-and-disinfection air filter system is a meaningful strategy to improve air quality since the residence time of an air purifier is so short that normal technology can rarely disinfect germs completely within such a short residence time.

\section{CONCLUSION}

In summary, $\mathrm{Cu}-\mathrm{CPP}$ was successfully deposited onto an amine- 
functionalized MS to produce an air filter of $\mathrm{Cu}-\mathrm{CPP} / \mathrm{MS}$. The porous nature of the melamine sponge, the integration of $\mathrm{Cu}-\mathrm{CPP}$ microcrystals greatly increased the capture efficacy of a $\mathrm{Cu}-\mathrm{CPP} /$ MS air filter due to electrostatic attraction between negatively charged bacterial cells and positively charged unbalanced copper ions within $\mathrm{Cu}-\mathrm{CPP}$. Additionally, Cu-CPP/MS exhibited excellent antibacterial activity due to the combined effect of the antibacterial activity stemming from $\mathrm{Cu}-\mathrm{CPP}$ as an anti-pathogenic agent. Since the residence time of pathogens in a general air purifier is too short to be disinfected, the capture-and-disinfection system is one of the most promising candidates to terminate pathogens in a single-pass air flow. These findings show that $\mathrm{Cu}-\mathrm{CPP} / \mathrm{MS}$ is a potential captureand-disinfection system. The obtained air filter is expected to be effective for tackling the ongoing pandemic of SARS-CoV-2.

\section{CONFLICT OF INTEREST}

The authors declare no conflict of interest.

\section{ACKNOWLEDGEMENT}

This work is financially supported by the Korea Ministry of Environment as Waste to Energy-Recycling Human Resource Development Project (YL-WE-21-001). This work is also supported by the Next Generation Carbon Upcycling Project (Project No. 2017 M1A2A2081060) through the National Research Foundation (NRF) funded by the Ministry of Science and ICT, Republic of Korea.

\section{SUPPORTING INFORMATION}

Additional information as noted in the text. This information is available via the Internet at http://www.springer.com/chemistry/ journal/11814.

\section{REFERENCES}

1. P. Zhou, X.-L. Yang, X.-G. Wang, B. Hu, L. Zhang, W. Zhang, H.-R. Si, Y. Zhu, B. Li, C.-L. Huang, H.-D. Chen, J. Chen, Y. Luo, H. Guo, R.-D. Jiang, M.-Q. Liu, Y. Chen, X.-R. Shen, X. Wang, X.-S. Zheng, K. Zhao, Q.-J. Chen, F. Deng, L.-L. Liu, B. Yan, F.-X. Zhan, Y.-Y. Wang, G.-F. Xiao and Z.-L. Shi, Nature, 579, 270 (2020).

2. F. Wu, S. Zhao, B. Yu, Y.-M. Chen, W. Wang, Z.-G. Song, Y. Hu, Z.-W. Tao, J.-H. Tian, Y.-Y. Pei, M.-L. Yuan, Y.-L. Zhang, F.-H. Dai, Y. Liu, Q.-M. Wang, J.-J. Zheng, L. Xu, E. C. Holmes and Y.-Z. Zhang, Nature, 579, 265 (2020).

3. P. Klaiber, J. H. Wen, A. DeLongis and N. L. Sin, J. Gerontol B Psychol. Sci. Soc. Sci., 76, e30 (2021).

4. J.S. Gaffney and N. A. Marley, ACS Symposium Series, 919, 286 (2005).

5. S. Asadi, A. S. Wexler, C. D. Cappa, S. Barreda, N. M. Bouvier and W. D. Ristenpart, Sci. Rep., 9, 2348 (2019).

6. Y. Liu, Z. Ning, Y. Chen, M. Guo, Y. Liu, N. K. Gali, L. Sun, Y. Duan, J. Cai, D. Westerdahl, X. Liu, K. Xu, K.-f. Ho, H. Kan, Q. Fu and K. Lan, Nature, 582, 557 (2020).

7. V. Stadnytskyi, C. E. Bax, A. Bax and P. Anfinrud, Proc. Natl. Acad. Sci., 117, 11875 (2020).
8. B. Wang, A. Zhang, J. L. Sun, H. Liu, J. Hu and L. X. Xu, J. Biomech. Eng., 127, 32 (2005).

9. K. W. Mui, L. T. Wong, C. L. Wu and A. C. K. Lai, J. Hazard. Mater., 167, 736 (2009).

10. F. J. García de Abajo, R. J. Hernández, I. Kaminer, A. Meyerhans, J. Rosell-Llompart and T. Sanchez-Elsner, ACS Nano, 14, 7704 (2020).

11. J. R. Passweg, P. A. Rowlings, K. A. Atkinson, A. J. Barrett, R. P. Gale, A. Gratwohl, N. Jacobsen, J. P. Klein, P. Ljungman, J. A. Russell, U.W. Schaefer, K. A. Sobocinski, J.M. Vossen, M. J. Zhang and M. M. Horowitz, Bone Marrow Transplant., 21, 1231 (1998).

12. I. Oren, N. Haddad, R. Finkelstein and J. M. Rowe, Am. J. Hematol., 66, 257 (2001).

13. R. Tellier, Emerging Infect. Dis., 12, 1657 (2006).

14. P. Wargocki, ASHRAE J., 57, 70+ (2015).

15. R. Maus, A. Goppelsröder and H. Umhauer, Atmos. Environ., 35, 105 (2001).

16. D. L. Price, R. B. Simmons, S. A. Crow Jr. and D. G. Ahearn, J. Ind. Microbiol. Biotechnol., 32, 319 (2005).

17. Y. Gilbert and C. Duchaine, Can. J. Civ. Eng., 36, 1873 (2009).

18. D. Menzies, Hdb Env Chem, 4, 151 (2005).

19. K. Bull, Travel Med. Infect. Dis., 6, 142 (2008).

20. J. C. B. Perrier, L. L. Coq, Y. Andrès and P. L. Cloirec, Int. J. Chem. React. Eng., 6, 1 (2008).

21. L. Morawska, J. W. Tang, W. Bahnfleth, P. M. Bluyssen, A. Boerstra, G. Buonanno, J. Cao, S. Dancer, A. Floto, F. Franchimon, C. Haworth, J. Hogeling, C. Isaxon, J. L. Jimenez, J. Kurnitski, Y. Li, M. Loomans, G. Marks, L. C. Marr, L. Mazzarella, A. K. Melikov, S. Miller, D. K. Milton, W. Nazaroff, P. V. Nielsen, C. Noakes, J. Peccia, X. Querol, C. Sekhar, O. Seppänen, S.-i. Tanabe, R. Tellier, K. W. Tham, P. Wargocki, A. Wierzbicka and M. Yao, Environ. Int., 142, 105832 (2020).

22. E. S. Mousavi, N. Kananizadeh, R. A. Martinello and J. D. Sherman, Environ. Sci. Technol. Lett., 55, 4134 (2020).

23. A. Umemura, S. Diring, S. Furukawa, H. Uehara, T. Tsuruoka and S. Kitagawa, J. Am. Chem. Soc., 133, 15506 (2011).

24. M. Shen, F. Forghani, X. Kong, D. Liu, X. Ye, S. Chen and T. Ding, Compr. Rev. Food Sci. Food Saf., 19, 1397 (2020).

25. J. Xiao, S. Chen, J. Yi, H. F. Zhang and G. A. Ameer, Adv. Funct. Mater., 27, 1604872 (2017).

26. J. P. Ruparelia, A. K. Chatterjee, S. P. Duttagupta and S. Mukherji, Acta Biomater., 4, 707 (2008).

27. C. Wu, Y. Zhou, W. Fan, P. Han, J. Chang, J. Yuen, M. Zhang and Y. Xiao, Biomaterials, 33, 2076 (2012).

28. P. Li, J. Li, X. Feng, J. Li, Y. Hao, J. Zhang, H. Wang, A. Yin, J. Zhou, X. Ma and B. Wang, Nat. Commun., 10, 2177 (2019).

29. L. Gritsch, C. Lovell, W. H. Goldmann and A. R. Boccaccini, Carbohydr. Polym., 179, 370 (2018).

30. S. S.-Y. Chui, S. M.-F. Lo, J. P. H. Charmant, A. G. Orpen and I. D. Williams, Science, 283, 1148 (1999).

31. A. R. Abbasi, K. Akhbari and A. Morsali, Ultrason. Sonochem., 19, 846 (2012).

32. K. Singbumrung, K. Motina, P. Pisitsak, P. Chitichotpanya, S. Wongkasemjit and T. Inprasit, Fibers Polym., 19, 1373 (2018).

33. H.E. Emam, O. M. Darwesh and R. M. Abdelhameed, Colloids Surf., B, 165, 219 (2018).

34. H. N. Rubin, B. H. Neufeld and M. M. Reynolds, ACS Appl. Mater. 
Interfaces, 10, 15189 (2018).

35. G. Ramya, O. Camus, Y. M. J. Chew, B. Crittenden and S. Perera, ACS Appl. Polym. Mater., 2, 1569 (2020).

36. L. Yu, G. K. Peel, F. H. Cheema, W. S. Lawrence, N. Bukreyeva, C. W. Jinks, J.E. Peel, J. W. Peterson, S. Paessler, M. Hourani and Z. Ren, Mater. Today Phys., 15, 100249 (2020).

37. Y. Chen, S. Zhang, S. Cao, S. Li, F. Chen, S. Yuan, C. Xu, J. Zhou, X. Feng, X. Ma and B. Wang, Adv. Mater., 29, 1606221 (2017).

38. Y. Feng and J. Yao, Ind. Eng. Chem. Res., 57, 7322 (2018).

39. P. Gamez, P. de Hoog, M. Lutz, A. L. Spek and J. Reedijk, Inorg. Chim. Acta, 351, 319 (2003).

40. A. B. Wiles, D. Bozzuto, C. L. Cahill and R. D. Pike, Polyhedron, 25, 776 (2006).

41. Y. Zhao, K. Watanabe and K. Hashimoto, J. Am. Chem. Soc., 134, 19528 (2012).

42. Y. Zhao, K. Watanabe and K. Hashimoto, J. Mater. Chem. A, 1, 1450 (2013).

43. R. Shanmugakala, P. Tharmaraj and C. D. Sheela, J. Mol. Struct., 1076, 606 (2014).

44. R. Shanmugakala, P. Tharmaraj, C. D. Sheela and N. Chidambaranathan, Med. Chem. Res., 23, 329 (2014).

45. Y. Ding, W. Xu, Y. Yu, H. Hou and Z. Zhu, ACS Appl. Mater. Interfaces, 10, 6652 (2018).

46. C.-H. Deng, J.-L. Gong, P. Zhang, G.-M. Zeng, B. Song and H.-Y. Liu, J. Colloid Interface Sci., 488, 26 (2017).

47. J. Pinto, D. Magrì, P. Valentini, F. Palazon, J. A. Heredia-Guerrero, S. Lauciello, S. Barroso-Solares, L. Ceseracciu, P. P. Pompa, A. Athanassiou and D. Fragouli, ACS Appl. Mater. Interfaces, 10, 16095 (2018).

48. G. B. Hwang, J. E. Lee, C. W. Nho, B. U. Lee, S. J. Lee, J. H. Jung and G.-N. Bae, Sci. Total Environ., 421-422, 273 (2012).

49. D. Y. Choi, K. J. Heo, J. Kang, E. J. An, S.-H. Jung, B. U. Lee, H. M. Lee and J. H. Jung, J. Hazard. Mater., 351, 29 (2018).

50. D. H. Park, Y. H. Joe, A. Piri, S. An and J. Hwang, J. Hazard. Mater, 396, 122640 (2020).

51. S. Ma, M. Zhang, J. Nie, B. Yang, S. Song and P. Lu, Cellulose, 25, 5999 (2018).

52. H. S. Rodríguez, J.P. Hinestroza, C. Ochoa-Puentes, C. A. Sierra and C. Y. Soto, J. Appl. Polym. Sci., 131, 40815 (2014).

53. M. J. Lis, B. B. Caruzi, G. A. Gil, R. B. Samulewski, A. Bail, F. A. P.
Scacchetti, M. P. Moisés and F. Maestá Bezerra, Polymers (Basel), 11, 713 (2019).

54. G. Lu, S. Li, Z. Guo, O. K. Farha, B. G. Hauser, X. Qi, Y. Wang, X. Wang, S. Han, X. Liu, J.S. DuChene, H. Zhang, Q. Zhang, X. Chen, J. Ma, S. C. J. Loo, W. D. Wei, Y. Yang, J.T. Hupp and F. Huo, Nat. Chem., 4, 310 (2012).

55. C.-H. Kuo, Y. Tang, L.-Y. Chou, B. T. Sneed, C. N. Brodsky, Z. Zhao and C.-K. Tsung, J. Am. Chem. Soc., 134, 14345 (2012).

56. A. Nasrullah, A. S. Khan, A. H. Bhat, I. U. Din, A. Inayat, N. Muhammad, E. M. Bakhsh and S. B. Khan, Renewable Energy, 168, 723 (2021).

57. H. Chen, L. Wang, J. Yang and R. T. Yang, J. Phys. Chem. C, 117, 7565 (2013).

58. H. Gao, P. Sun, Y. Zhang, X. Zeng, D. Wang, Y. Zhang, W. Wang and J. Wu, Surf. Coat. Technol., 339, 147 (2018).

59. H. Zhou, T. Zhang, X. Yue, Y. Peng, F. Qiu and D. Yang, Ind. Eng. Chem. Res., 58, 4844 (2019).

60. S. Loera-Serna, M. A. Oliver-Tolentino, M. de Lourdes LópezNúñez, A. Santana-Cruz, A. Guzmán-Vargas, R. Cabrera-Sierra, H. I. Beltrán and J. Flores, J. Alloys Compd., 540, 113 (2012).

61. R. Riccò, O. Linder-Patton, K. Sumida, M. J. Styles, K. Liang, H. Amenitsch, C. J. Doonan and P. Falcaro, Chem. Mater, 30, 5630 (2018).

62. K. Ma, Y. Wang, Z. Chen, T. Islamoglu, C. Lai, X. Wang, B. Fei, O. K. Farha and J. H. Xin, ACS Appl. Mater. Interfaces, 11, 22714 (2019).

63. Y. Zhang, S. Yuan, X. Feng, H. Li, J. Zhou and B. Wang, J. Am. Chem. Soc., 138, 5785 (2016).

64. T.-T. Li, X. Cen, H.-T. Ren, L. Wu, H.-K. Peng, W. Wang, B. Gao, C.-W. Lou and J.-H. Lin, ACS Appl. Mater. Interfaces, 12, 8730 (2020).

65. Z. Li, J. Ma, J. Ruan and X. Zhuang, Nanoscale Res. Lett., 14, 195 (2019).

66. A. Rauf, J. Ye, S. Zhang, Y. Qi, G. Wang, Y. Che and G. Ning, Dalton Trans., 48, 17810 (2019).

67. R. Kumar and H. Münstedt, Biomaterials, 26, 2081 (2005).

68. B. Li, Y. Li, Y. Zhao and L. Sun, J. Phys. Chem. Solids, 74, 1842 (2013).

69. M. Shen, F. Forghani, X. Kong, D. Liu, X. Ye, S. Chen and T. Ding, Compr. Rev. Food Sci. Food Saf., 19, 1397 (2020). 